\title{
Aplikasi 1-Methylcyclopropene untuk Meningkatkan Vase life Bunga Potong Zingiber spectabile Griff. Silvana
}

\author{
Application of1-methylcyclopropene to Increase the Vase Life of Zingiber $\underline{\text { spectabile }}$ \\ Griff. Silvana Flowers
}

\author{
Juang Gema Kartika ${ }^{1 *}$ dan Tiara Adyantari ${ }^{1}$
}

Diterima 4 Maret 2014/Disetujui 21 Juli 2014

\begin{abstract}
The freshness of Zingiber spectabile Griff Silvana (bihip) as cut flowers must be maintained by the appropriate post-harvest treatment. One of the post-harvest technologies that is commonly used is the use of chemical 1-Methylcyclopropene (1-MCP). This study was aimed to extend the vase life of bihip flowers using 1-MCP to gain optimum concentration of 1-MCP that can extend the vase life of bihip flowers, and to find the best application technique of 1-MCP for longest vase life of bihip flowers. This study used a completely randomized design (CRD) factorial with two factors. The first factor was the concentration of 1-MCP that consists of five levels; 0 ppm (A0), $0.001 \mathrm{ppm}(\mathrm{Al})$, $0.002 \mathrm{ppm}(\mathrm{A2}), 0.003 \mathrm{ppm}(\mathrm{A3})$, and $0.004 \mathrm{ppm}$ (A4). The second factor was application technique of 1-MCP : sprayed (B1) and soaked (B2). The results showed that 1-MCP significantly extended the vase life of cut flowers bihip flowers up to 11.30 day compared to control which was only 9.55 day. Concentration 0.004 ppm of 1-MCP was able to extend optimum vase life of cut flowers bihip until 11.30 day. Method of 1-MCP application to efficiently extend bihip flowers until 11.10 day was soaking in a solution of 1-MCP. The combination treatment of 1-MCP to extend the vase life of bihip flowers was 1-MCP treatment concentration of 0.004 ppm and soaking treatment. Treatment with 1MCP at 0.004 ppm extended bihip flowers vase life.
\end{abstract}

Key words: 1-Methylcyclopropene, bihip flowers, vase life, Zingiber spectabile Griff. Silvana

\begin{abstract}
ABSTRAK
Bunga potong Zingiber spectabile Griff. Silvana (bihip) perlu dipertahankan kesegarannya dengan cara perlakuan pasca panen yang tepat. Salah satu teknologi pasca panen adalah penggunaan bahan kimia 1-Methylcyclopropene (1-MCP). Penelitian ini bertujuan untuk memperpanjang vase life bunga bihip dengan menggunakan 1-MCP, mendapatkan konsentrasi 1-MCP optimum yang dapat memperpanjang vase life bunga bihip, dan mencari cara aplikasi yang efisien untuk memperpanjang vase life bunga bihip. Penelitian ini menggunakan rancangan acak lengkap (RAL) Faktorial dengan 2 faktor yaitu konsentrasi 1-MCP dan metoda aplikasi 1-MCP. Konsentrasi 1-MCP terdiri dari lima taraf: 0 ppm (A0), $0.001 \mathrm{ppm}$ (A1), $0.002 \mathrm{ppm}$ (A2), $0.003 \mathrm{ppm}$ (A3), dan 0.004 ppm (A4). Caraaplikasi 1-MCP terdiri atas dua taraf: disemprot (B1) dan direndam (B2). Hasil penelitian menunjukkan bahwa 1-MCP secara nyata dapat memperpanjang vase life bunga potong bihip hingga mencapai 11.30 hari dibandingkan dengan tanpa perlakuan 1-MCP yaitu hanya 9.55 hari. Konsentrasi 1-MCP yang optimum untuk memperpanjang vase life bunga potong bihip hingga 11.30 hari yaitu dengan konsentrasi $0.004 \mathrm{ppm}$. Cara aplikasi 1-MCP yang efisien untuk memperpanjang bunga bihip hingga 11.10 hari yaitu dengan cara merendam bunga dalam larutan 1MCP. Kombinasi perlakuan 1-MCP yang dapat memperpanjang vase life bunga bihip yaitu perlakuan 1-MCP konsentrasi 0.004 ppm dengan cara aplikasi direndam.
\end{abstract}

Kata kunci: 1-Methylcyclopropene, bihip, vase life, Zingiber spectabile Griff. Silvana

${ }^{1}$ Departemen Agronomi dan Hortikultura, Fakultas Pertanian, Institut Pertanian Bogor (Bogor Agricultural University), J1. Meranti, Kampus IPB Dramaga, Bogor 16680, Indonesia Telp.\&Faks. 62-251-8629353 e-mail korespondensi: ika_juang@yahoo.com 


\section{PENDAHULUAN}

Bunga telah menjadi bagian dari kehidupan masyarakat Indonesia. Perhatian masyarakat terhadap bunga semakin meningkat bila dibandingkan dengan beberapa tahun yang lalu. Minat masyarakat untuk membudidayakan bunga secara komersial juga meningkat sejalan dengan meningkatnya permintaan pasar. Beberapa jenis bunga potong tropis tumbuh dan berkembang baik di Indonesia. Data produksi bunga potong pada tahun 2012 sebesar 581317792 tangkai dan tahun 2013 sebesar 697865570 tangkai dengan tingkat pertumbuhan sebesar $20.05 \%$. Tingginya tingkat produksi bunga potong di Indonesia pun diikuti oleh volume impor yang cukup tinggi yaitu sebesar 12906.02 ton, hal tersebut diakibatkan oleh tingginya permintaan masyarakat akan bunga potong dan tanaman hias lainnya (Direktorat Jenderal Hortikultura, 2014).

Indonesia sebagai negara tropika memiliki potensi untuk mengembangkan berbagai jenis tanaman hias tropis termasuk bihip dibandingkan dengan negara-negara berikilim subtropik. Bunga potong ini juga menjadi salah satu komoditas ekspor Indonesia. Aplikasi perlakuan pascapanen yang tepat sangat diperlukan untuk menjaga kesegaran bunga. Menurut Balai Penelitian Tanaman Hias (2011), lama kesegaran bunga potong bihip tanpa pemberian bahan pengawet dapat mencapai 7 hari dan bunga ini responsif terhadap bahan pengawet. Perlakuan pasca panen yang dilakukam pada bunga potong bihip ini antara lain disimpan pada suhu rendah dengan kelembaban yang tinggi dan dilakukan dengan merendam tangkai bunga dalam air serta menghindari penyimpanan dalam kondisi kering.

Bihip (Zingiber spectabile Griff. Silvana) merupakan bunga potong tropis dari famili Zingiberaceae yang mempunyai keunggulan beradaptasi luas dari dataran rendah sampai tinggi (Larsen et al., 1999). Bunganya merupakan susunan braktea yang mempunyai warna kuning yang berkembang menjadi semburat merah yang menarik, bentuk yang gagah dan unik, dapat dipanen dalam ukuran diameter kecil sampai besar, mempunyai tangkai bunga yang panjang dan sangat diminati para perangkai bunga maupun dekorator.
Penurunan kesegaran bunga tidak dapat dihentikan namun dapat diperlambat dengan cara penanganan panen dan pascapanen yang baik dan tepat. Salah satu teknologi pasca panen yang kini sudah mulai diterapkan di beberapa negara adalah penggunaan bahan kimia sebagai bahan pengawet berupa 1Methylcyclopropene (1-MCP). 1-MCP adalah suatu senyawa volatil turunan cyclopropene yaitu cyclic olefin yang memiliki kemampuan memblokir reseptor penangkap etilen sehingga mampu memperpanjang umur pajang dan mempertahankan kualitas produk hortikultura (Sisler dan Serek, 1997). Pengembangan teknologi pascapanen bunga potong dengan aplikasi 1-MCP di Indonesia memerlukan pengujian lebih lanjut karena penggunaan 1MCP ini sebagian besar digunakan untuk komoditi hortikultura khususnya buah. Dalam penelitian ini akan dikaji aplikasi untuk mempertahankan kesegaran bunga potong bihip selama penyimpanan.

Berdasarkan permasalahan tersebut, penelitian ini bertujuan untuk memperpanjang vase life bunga bihip dengan menggunakan 1MCP, mendapatkan konsentrasi 1-MCP optimum yang dapat memperpanjang vase life bunga bihip, dan mencari cara aplikasi yang efisien untuk memperpanjang vase life bunga bihip.

\section{METODE PENELITIAN}

Penelitian ini dilaksanakan pada bulan Desember 2013 - Februari 2014 di laboratorium pascapanen Departemen Agronomi dan Hortikultura IPB. Bahan utama penelitian ini adalah bunga potong bihip dari pasar Rawa Belong Jakarta. Bahan utama lain yang digunakan adalah 1-Methylcyclopropene (1-MCP), gula pasir, dan air. Alat yang digunakan yaitu box plastik (container), toples plastik, hand sprayer, gelas ukur, pisau, plastik penutup, kertas label, alat tulis, timbangan digital.

Penelitian ini menggunakan Rancangan Acak Lengkap (RAL) Faktorial dengan 2 faktor. Faktor pertama ialah konsentrasi 1MCP yang terdiri dari lima taraf: 0 ppm (A0), $0.001 \mathrm{ppm}$ (A1), $0.002 \mathrm{ppm}$ (A2), $0.003 \mathrm{ppm}$ (A3), dan 0.004 ppm (A4). Faktor kedua yaitu cara aplikasi 1-MCP terdiri atas dua taraf: disemprot (B1) dan direndam (B2). Percobaan ini terdiri atas 10 ulangan, setiap ulangan 
memerlukan 1 tangkai bunga bihip sehingga penelitian ini memerlukan 100 tangkai bunga bihip. Data yang diperoleh dianalisis dengan menggunakan uji sidik ragam (uji F) pada taraf $5 \%$. Jika menunjukkan pengaruh yang nyata terhadap hasil pengamatan maka dilakukan analisis uji lanjut Duncan Multiple Range Test (DMRT) pada taraf nyata 5\%. Data diolah menggunakan SAS. Penelitian ini diawali dengan tahapan survei bunga di pasar Rawa Belong dan membeli 1-MCP di Mandiri Jaya Flora. Bunga potong bihip dibeli pada pagi hari untuk mencegah bunga mengalami dehidrasi berlebihan selama transportasi. Bunga bihip kemudian dibawa ke Laboratorium Pascapanen Departemen Agronomi dan Hortikultura IPB menggunakan mobil yang berpendingin. Setelah sampai di labora-torium dilakukan penyortiran bunga berdasarkan kondisi keutuhan braktea, warna bunga, dan panjang tangkai.

Perlakuan aplikasi 1-MCP dengan cara disemprot. Pada tahap perlakuan aplikasi 1MCP dengan cara disemprot, bunga bihip disemprot larutan 1-MCP dengan menggunakan hand sprayer. Serbuk 1-MCP ditimbang sesuai dengan konsentrasi yang akan diaplikasikan dengan menggunakan timbangan digital. Cara menghitung banyaknya serbuk 1-MCP yang digunakan:

$$
\begin{aligned}
X & =\frac{\text { konsentrasi yang diharapkan .volume air }}{\text { Bahan aktif yang terkandung }} \\
X & =\frac{0.001 \mathrm{ppm} \cdot 1 \text { liter }}{0.014 \%}=\frac{0.001 \mathrm{mg} / \mathrm{L} \cdot 1 \mathrm{~L}}{0.014 \%} \\
& =0.714 \mathrm{mg}=0.00714 \mathrm{~g}
\end{aligned}
$$

Larutan 1-MCP sebanyak 1L yang berkonsentrasi 0.001 ppm membutuhkan serbuk 1-MCP sebanyak 0.00714 g. Bunga bihip sebanyak 10 tangkai yang akan diberi perlakuan disimpan dalam container dengan posisi braktea yang bersilangan kemudian disemprot dengan larutan 1-MCP.

Setelah diaplikasi larutan 1-MCP dengan cara disemprot, bunga disimpan secara vertikal dalam toples plastik yang telah diisi larutan holding $15 \%$ (air+gula) dan diberi plastik penutup kemudian diamati setiap hari sampai masa simpan bunga potong berakhir serta tangkai bunga dipotong sepanjang $1 \mathrm{~cm}$ setiap 2 hari sekali untuk mencegah terjadinya embolism (hambatan penyerapan air karena adanya gelembung udara di dalam pembuluh xylem).

Perlakuan aplikasi 1-MCP dengan cara perendaman bunga potong dalam larutan 1MCP. Pada tahap perlakuan aplikasi 1-MCP dengan cara direndam, bunga bihip direndam dengan larutan 1-MCP. Serbuk 1-MCP ditimbang sesuai dengan konsentrasi yang akan diaplikasikan dengan menggunakan timbangan digital. Cara menghitung banyaknya serbuk 1-MCP yang digunakan:

$$
\begin{aligned}
X & =\frac{\text { konsentrasi yang diharapkan } . \text { volume air }}{\text { Bahan aktif yang terkandung }} \\
X & =\frac{0.001 \mathrm{ppm} .20 \mathrm{~L}}{0.014 \%}=\frac{0.001 \mathrm{mg} / \mathrm{L} .20 \mathrm{~L}}{0.014 \%} \\
& =142.86 \mathrm{mg}=0.14 \mathrm{~g}
\end{aligned}
$$

Larutan 1-MCP sebanyak $20 \mathrm{~L}$ yang berkonsentrasi 0.001 ppm membutuhkan serbuk 1-MCP sebanyak $0.14 \mathrm{~g}$. Bunga bihip sebanyak 10 tangkai yang akan diberi perlakuan disimpan dalam box plastik yang ditutup rapat dengan posisi braktea yang bersilangan kemudian direndam dalam larutan 1-MCP selama 5 menit.

Setelah diaplikasi larutan 1-MCP dengan cara direndam, bunga disimpan secara vertikal dalam toples plastik yang telah diisi larutan holding $15 \%$ (air+gula) dan diberi plastik penutup kemudian diamati setiap hari sampai masa simpan bunga potong berakhir serta tangkai bunga dipotong sepanjang $1 \mathrm{~cm}$ setiap 2 hari sekali untuk mencegah terjadinya embolism.

Pengamatan dilakukan pada bunga potong bihip pada saat sebelum dan sesudah diberi perlakuan 1-MCP dan setelah itu juga diamati setiap hari sampai masa simpan bunga bihip berakhir, kecuali uji hedonik yang dilakukan dua hari sekali. Satuan pengamatan yang diamati meliputi warna braktea, warna tangkai, susut bobot, uji hedonik bunga, dan vase life (masa pajang).

\section{HASIL DAN PEMBAHASAN}

\section{Kondisi Umum}

Bahan percobaan yang digunakan dalam penelitian ini yaitu bunga potong bihip. Kriteria bunga yang digunakan antara lain 
diameter braktea 6-7 $\mathrm{cm}$ berbentuk memanjang berwarna kuning, kondisi braktea segar, berwarna kuning, panjang tangkai 60-75 $\mathrm{cm}$ dan mempunyai bunga biologi sebanyak $50 \%$ masih kuncup. Menurut Direktorat Budidaya Tanaman Hias (2006), panjang braktea dapat mencapai lebih dari $25 \mathrm{~cm}$ dengan diameter braktea $8,2 \mathrm{~cm}$, dan jumlah braktea 159 helai yang berarti jumlah bunga biologi sama dengan jumlah helai braktea. Selang waktu dari panen bunga potong bihip hingga diberi perlakuan dengan 1-MCP yaitu 15 jam.

\section{Warna Braktea}

Braktea merupakan daun pelindung yang menyerupai mahkota bunga. Braktea bunga bihip berwarna kuning dan hal yang membedakan warna braktea selama penyimpanan yaitu adanya warna kecoklatan pada braktea, semakin panjang vase life maka perubahan warna braktea menjadi coklat semakin lambat. Kondisi braktea diamati secara visual dengan menggunakan skala warna yaitu $4=$ kuning, $3=$ kuning pucat, $2=$ kuning kecoklatan, dan $1=$ coklat.

Warna braktea bunga bihip antara 3-11 HSP dipengaruhi oleh interaksi konsentrasi dan metoda aplikasi 1-MCP (Tabel 1). Secara tunggal perlakuan konsentrasi 1-MCP berpengaruh nyata pada 3 HSP, 8 HSP, 11 HSP, dan 12 HSP. Perlakuan cara aplikasi 1MCP menunjukkan pengaruh nyata pada 4 HSP, 5 HSP, 6 HSP, 7 HSP, dan 10 HSP.

Tabel 1. Rekapitulasi analisis ragam pengaruh perlakuan konsentrasi dan cara aplikasi 1-MCP terhadap warna braktea bunga potong bihip

\begin{tabular}{|c|c|c|c|c|}
\hline Periode & $\begin{array}{c}\text { Konsentrasi } \\
\text { (A) }\end{array}$ & $\begin{array}{c}\text { Aplik } \\
\text { asi } \\
\text { (B) }\end{array}$ & $\begin{array}{c}\text { Intera } \\
\text { ksi } \\
\mathrm{AxB}\end{array}$ & $\mathrm{KK}(\%)$ \\
\hline $1 \mathrm{HSP}$ & tn & tn & tn & 0.00 \\
\hline 2 HSP & tn & tn & tn & 0.00 \\
\hline 3 HSP & $* *$ & tn & $* *$ & 3.85 \\
\hline 4 HSP & tn & $*$ & * & 8.59 \\
\hline $5 \mathrm{HSP}$ & tn & $* *$ & $* *$ & 27.65 \\
\hline 6 HSP & tn & $* *$ & $* *$ & 27.35 \\
\hline 7 HSP & tn & $* *$ & $* *$ & $15.61^{\mathrm{Tr}}$ \\
\hline 8 HSP & $* *$ & tn & $* *$ & 29.90 \\
\hline 9 HSP & tn & tn & $* *$ & 23.66 \\
\hline 10 HSP & tn & $* *$ & $*$ & $15.65^{\mathrm{Tr}}$ \\
\hline $11 \mathrm{HSP}$ & $* *$ & tn & $*$ & 22.97 \\
\hline $12 \mathrm{HSP}$ & $* *$ & tn & tn & 23.47 \\
\hline Keterangan: & \multicolumn{4}{|c|}{$\begin{array}{l}\text { *: Berpengaruh nyata pada taraf 5\%; } \\
\text { **: Berpengaruh sangat nyata pada taraf } 1 \% \\
\text { tn: Tidak berpengaruh nyata; Tr: hasi } \\
\text { transformasi akar. }\end{array}$} \\
\hline
\end{tabular}

Tabel 2. Warna braktea bunga potong bihip pada berbagai konsentrasi dan cara aplikasi 1-MCP

\begin{tabular}{|c|c|c|c|c|c|c|c|c|c|c|c|c|}
\hline \multirow{2}{*}{ Perlakuan } & \multicolumn{12}{|c|}{ Umur Bunga (HSP) } \\
\hline & 1 & 2 & 3 & 4 & 5 & 6 & 7 & 8 & 9 & 10 & 11 & 12 \\
\hline \multicolumn{13}{|l|}{$\begin{array}{l}\text { Konsentrasi } \\
\text { (A) }\end{array}$} \\
\hline $0.000 \mathrm{ppm}$ & 4 & 4 & $3.85 b$ & 3.75 & 2.5 & 2.4 & 2 & $1.95 \mathrm{c}$ & $1.75 b$ & 1.5 & $1.50 \mathrm{~b}$ & $1.22 \mathrm{ab}$ \\
\hline $0.001 \mathrm{ppm}$ & 4 & 4 & $4.00 \mathrm{a}$ & 4 & 2.85 & 2.75 & 2.55 & $2.65 \mathrm{ab}$ & $2.00 \mathrm{ab}$ & 1.7 & $1.08 \mathrm{~b}$ & $1.00 \mathrm{~b}$ \\
\hline $0.002 \mathrm{ppm}$ & 4 & 4 & $4.00 \mathrm{a}$ & 3.85 & 2.8 & 2.75 & 2.45 & $2.20 \mathrm{bc}$ & $2.28 \mathrm{a}$ & 1.83 & $1.73 \mathrm{a}$ & $1.00 \mathrm{~b}$ \\
\hline $0.003 \mathrm{ppm}$ & 4 & 4 & $4.00 \mathrm{a}$ & 3.85 & 2.85 & 2.8 & 2.45 & $2.50 \mathrm{abc}$ & $2.25 \mathrm{a}$ & 1.56 & $1.80 \mathrm{a}$ & $1.75 \mathrm{a}$ \\
\hline $0.004 \mathrm{ppm}$ & 4 & 4 & $4.00 \mathrm{a}$ & 3.95 & 3.15 & 3.05 & 2.7 & $3.00 \mathrm{a}$ & $2.37 \mathrm{a}$ & 2 & $1.90 \mathrm{a}$ & $1.89 \mathrm{a}$ \\
\hline Anova & tn & tn & $* *$ & tn & tn & tn & tn & $* *$ & $*$ & tn & $* *$ & $* *$ \\
\hline \multicolumn{13}{|l|}{ Aplikasi (B) } \\
\hline Disemprot & 4 & 4 & 3.94 & $3.80 \mathrm{~b}$ & $2.62 \mathrm{~b}$ & $2.54 b$ & $2.08 \mathrm{~b}$ & 2.29 & 2.08 & $1.46 \mathrm{~b}$ & 1.64 & 1.22 \\
\hline Direndam & 4 & 4 & 4 & $3.96 \mathrm{a}$ & $3.04 \mathrm{a}$ & $2.96 a$ & $2.76 \mathrm{a}$ & 2.61 & 2.2 & $1.95 \mathrm{a}$ & 1.45 & 1.67 \\
\hline Anova & tn & tn & tn & $*$ & $* *$ & $* *$ & $* *$ & tn & tn & $* *$ & tn & tn \\
\hline Interaksi AxB & tn & tn & $* *$ & $*$ & $* *$ & $* *$ & $* *$ & $* *$ & $* *$ & $*$ & $*$ & $\operatorname{tn}$ \\
\hline KK & 0 & 0 & 3.85 & 8.59 & 27.65 & 27.35 & 15.61 & 29.9 & 23.66 & 15.65 & 22.97 & 23.47 \\
\hline
\end{tabular}


Data pada Tabel 2 menunjukkan bahwa pada 1 HSP semua braktea bunga bihip menunjukkan warna kuning. Bunga bihip yang tidak diberi perlakuan 1-MCP warna brakteanya sudah mencapai skoring 2 yaitu perubahan warna menjadi kuning kecoklatan pada 5 HSP dan mencapai puncaknya pada 7 HSP sementara pemberian 1-MCP terlihat mampu menunda perubahan warna braktea bunga bihip. Bunga bihip yang diberi perlakuan 1-MCP dengan konsentrasi 0.4 ppm mencapai nilai skoring 2 pada 10 HSP. Sementara itu bunga bihip yang diberi perlakuan 1-MCP dengan cara aplikasi direndam mencapai nilai skoring 2 pada 10 HSP.

Bunga bihip yang diberi perlakuan 1MCP mengalami perubahan warna yang lebih lambat dibandingkan dengan yang tidak diberi perlakuan 1-MCP. Hal tersebut membuktikan bahwa pengaplikasian 1-MCP mampu menunda perubahan warna braktea. Berdasarkan hasil penelitian Salsabila (2013) bahwa bunga potong kasturi yang diaplikasikan 1-MCP waktu menghitamnya braktea lebih lambat dibandingkan yang tidak diaplikasikan 1-MCP. Menurut Blakenship dan Dole (2003) 1-MCP dapat memperlambat degradasi klorofil dan protein, jenis perubahan warna yang terjadi pada beberapa bagian tanaman dapat diperlambat dan dicegah dengan penggunaan 1-MCP.

\section{Warna Tangkai}

Warna tangkai pada bunga potong bihip merupakan salah satu ukuran yang menunjukkan kesegaran secara visual. Perubahan warna tangkai bunga diamati secara visual dengan membuat tingkatan perubahan warna (skala warna) yaitu $4=$ hijau, $3=$ hijau pucat, $2=$ hijau kecoklatan, dan 1=coklat. Degradasi pigmen warna merupakan gejala umum kebanyakan senesen bunga potong.

Rekapitulasi analisis sidik ragam menunjukkan interaksi yang nyata antara perlakuan konsentrasi 1-MCP dengan cara aplikasi 1-MCP terhadap warna tangkai bunga potong bihip yaitu dimulai pada 7 HSP, 10 HSP, dan 12 HSP. Secara tunggal perlakuan konsentrasi 1-MCP berpengaruh nyata pada 9 HSP dan 11 HSP. Perlakuan cara aplikasi 1MCP menunjukkan pengaruh nyata pada 5 HSP, 7 HSP, 9 HSP, dan 12 HSP (Tabel 3).
Tabel 3. Rekapitulasi analisis ragam pengaruh perlakuan konsentrasi dan cara aplikasi 1-MCP terhadap warna tangkai bunga potong bihip

\begin{tabular}{|c|c|c|c|c|}
\hline Periode & $\mathrm{K}(\mathrm{A})$ & A (B) & $\begin{array}{c}\mathrm{I} \\
\mathrm{AxB}\end{array}$ & KK $(\%)$ \\
\hline $1 \mathrm{HSP}$ & tn & th & tn & 0.00 \\
\hline 2 HSP & tn & tn & tn & 0.00 \\
\hline 3 HSP & tn & tn & tn & 0.00 \\
\hline 4 HSP & tn & tn & tn & 5.38 \\
\hline 5 HSP & tn & $* *$ & tn & $12.96^{\operatorname{Tr}}$ \\
\hline $6 \mathrm{HSP}$ & tn & tn & tn & 29.47 \\
\hline 7 HSP & tn & $*$ & $*$ & $13.22^{\operatorname{Tr}}$ \\
\hline 8 HSP & tn & tn & tn & 21.57 \\
\hline 9 HSP & $* *$ & $*$ & tn & 17.46 \\
\hline 10 HSP & tn & tn & $*$ & $11.91^{\operatorname{Tr}}$ \\
\hline $11 \mathrm{HSP}$ & $*$ & tn & tn & $11.00^{\operatorname{Tr}}$ \\
\hline 12 HSP & tn & $*$ & $*$ & 23.33 \\
\hline terangan: & $\begin{array}{l}\text { *: Berp } \\
\text { Berpen } \\
\text { Konsen } \\
\text { Tidak } \\
\text { transfor }\end{array}$ & $\begin{array}{l}\text { hh } \mathrm{n} \\
\text { sang } \\
\text { A: } \\
\text { enga } \\
\text { akar. }\end{array}$ & $\begin{array}{l}\text { pada } \\
\text { ata pad } \\
\text { casi, I: }\end{array}$ & $\begin{array}{l}\text { araf } 5 \% \text {; **: } \\
\text { taraf } 1 \% \text {; K: } \\
\text { Interaksi, tn: } \\
\text { Tr: hasil } \\
\quad\end{array}$ \\
\hline
\end{tabular}

Data pada tabel 4 menunjukkan bahwa pada 1 HSP hampir semua tangkai berwarna hijau namun selama pengamatan berlangsung semua tangkai mengalami perubahan warna hingga mencapai warna coklat pada akhir pengamatan. Bunga bihip yang diberi perlakuan 1-MCP dengan konsentrasi 0.004 ppm mengalami perubahan warna tangkai yang lebih lama dibandingkan yang tidak diberi perlakuan.

Menurut Bhattarchajee dan De (2005), respirasi dan transpirasi menyebabkan terjadinya senesen serta berkurangnya kandungan karbohidrat pada daun dan tangkai. Selama periode senesen terjadi penuruan kandungan amilum atau tepung, polisakarida dinding sel, protein, dan asam nukleat. Penurunan kandungan gula akan diikuti pengurangan kandungan lemak dan protein pada jaringan. Protein yang berkurang menyebabkan degradasi pigmen warna, lepasnya pigmen warna dari lapisan pelindung protein akan menyebabkan perubahan warna. 
Tabel 4. Warna tangkai bunga potong bihip pada berbagai konsentrasi dan cara aplikasi 1-MCP

\begin{tabular}{|c|c|c|c|c|c|c|c|c|c|c|c|c|}
\hline \multirow{2}{*}{ Perlakuan } & \multicolumn{12}{|c|}{ Umur Bunga (HSP) } \\
\hline & 1 & 2 & 3 & 4 & 5 & 6 & 7 & 8 & 9 & 10 & 11 & 12 \\
\hline \multicolumn{13}{|l|}{ Konsentrasi (A) } \\
\hline $0.000 \mathrm{ppm}$ & 4.00 & 4.00 & 4.00 & 3.85 & 2.85 & 2.60 & 1.85 & 1.86 & $1.92 \mathrm{a}$ & 1.67 & $1.22 b c$ & 2.00 \\
\hline $0.001 \mathrm{ppm}$ & 4.00 & 4.00 & 4.00 & 4.00 & 3.00 & 2.60 & 2.40 & 2.23 & $1.76 \mathrm{ab}$ & 1.29 & $1.08 \mathrm{c}$ & 1.00 \\
\hline $0.002 \mathrm{ppm}$ & 4.00 & 4.00 & 4.00 & 4.00 & 2.60 & 2.30 & 2.30 & 2.00 & $1.94 \mathrm{a}$ & 1.44 & $1.36 \mathrm{bc}$ & 1.00 \\
\hline $0.003 \mathrm{ppm}$ & 4.00 & 4.00 & 4.00 & 4.00 & 2.90 & 2.45 & 1.90 & 2.14 & $1.64 b$ & 1.36 & $1.60 \mathrm{ab}$ & 1.50 \\
\hline $0.004 \mathrm{ppm}$ & 4.00 & 4.00 & 4.00 & 4.00 & 2.75 & 2.40 & 2.05 & 2.06 & $2.00 \mathrm{a}$ & 1.62 & $1.80 \mathrm{a}$ & 1.67 \\
\hline Anova & tn & tn & tn & tn & tn & tn & tn & tn & $* *$ & tn & $*$ & tn \\
\hline \multicolumn{13}{|l|}{ Aplikasi (B) } \\
\hline Disemprot & 4.00 & 4.00 & 4.00 & 3.94 & $2.58 \mathrm{~b}$ & 2.38 & $1.94 b$ & 2.03 & $1.79 \mathrm{a}$ & 1.39 & 1.43 & $1.00 \mathrm{~b}$ \\
\hline Direndam & 4.00 & 4.00 & 4.00 & 4.00 & $3.06 \mathrm{a}$ & 2.56 & $2.26 \mathrm{a}$ & 2.09 & $1.91 \mathrm{a}$ & 1.52 & 1.36 & $1.67 \mathrm{a}$ \\
\hline Anova & tn & tn & tn & tn & $* *$ & tn & $*$ & tn & $*$ & tn & tn & $*$ \\
\hline Interaksi AxB & tn & tn & tn & tn & tn & tn & $*$ & tn & tn & $*$ & tn & $*$ \\
\hline KK & 0 & 0 & 0 & 5.38 & 12.96 & 29.47 & 13.22 & 21.57 & 17.46 & 11.91 & 11.00 & 23.33 \\
\hline
\end{tabular}

\section{Susut Bobot}

Bunga potong akan mengalami kehilangan air secara terus menerus seiring dengan berjalannya waktu setelah panen khususnya pada saat penyimpanan (Santoso, 2012). Bunga bihip mengalami susut bobot selama pengamatan berlangsung.

Tabel 5. Rekapitulasi analisis ragam pengaruh perlakuan konsentrasi dan cara aplikasi 1-MCP terhadap persentase susut bobot bunga potong bihip

\begin{tabular}{|c|c|c|c|c|}
\hline Periode & $\begin{array}{c}K \\
\text { (A) }\end{array}$ & $\begin{array}{c}\mathrm{A} \\
\text { (B) }\end{array}$ & $\begin{array}{c}\mathrm{I} \\
\mathrm{AxB}\end{array}$ & $\mathrm{KK}(\%)$ \\
\hline $1 \mathrm{HSP}$ & $* *$ & $* *$ & tn & $19.13^{\operatorname{Tr}}$ \\
\hline 2 HSP & $* *$ & $* *$ & tn & 21.06 \\
\hline 3 HSP & $* *$ & $* *$ & tn & 15.30 \\
\hline 4 HSP & $* *$ & $* *$ & tn & 13.09 \\
\hline 5 HSP & $* *$ & tn & tn & 11.91 \\
\hline 6 HSP & $* *$ & $\operatorname{tn}$ & $\operatorname{tn}$ & 11.83 \\
\hline 7 HSP & $*$ & tn & $*$ & 11.91 \\
\hline 8 HSP & tn & tn & $* *$ & 11.67 \\
\hline 9 HSP & $\operatorname{tn}$ & tn & tn & 11.24 \\
\hline 10 HSP & tn & tn & tn & 11.06 \\
\hline $11 \mathrm{HSP}$ & tn & tn & tn & 10.39 \\
\hline 12 HSP & tn & $\operatorname{tn}$ & tn & 10.45 \\
\hline Keterangan: & \multicolumn{4}{|c|}{$\begin{array}{l}\text { *: Berpengaruh nyata pada taraf } 5 \% \text {; **: } \\
\text { Berpengaruh sangat nyata pada taraf } 1 \% \text {; K: } \\
\text { Konsentrasi, A: Aplikasi, I: Interaksi, tn: } \\
\text { Tidak berpengaruh nyata; Tr: hasil } \\
\text { transformasi akar. }\end{array}$} \\
\hline
\end{tabular}

Rekapitulasi analisis sidik ragam menunjukkan bahwa adanya interaksi yang nyata antara perlakuan konsentrasi 1-MCP dengan cara aplikasi 1-MCP terhadap susut bobot bunga potong bihip yaitu hanya pada 7 hari setelah perlakuan (HSP) dan 8 HSP. Secara tunggal perlakuan konsentrasi 1-MCP berpengaruh nyata pada 1 HSP hingga 7 HSP. Perlakuan cara aplikasi 1-MCP menunjukkan pengaruh nyata pada 1 HSP hingga 4 HSP (Tabel 5).

Data pada tabel 6 menunjukkan bahwa bunga bihip yang tidak diberi perlakuan 1MCP mengalami peningkatan persentase susut bobot yang lebih besar dibandinngkan dengan bunga bihip yang diberi perlakuan 1-MCP. Bunga bihip yang diberi perlakuan 1-MCP konsentrasi $0.004 \mathrm{ppm}$ mengalami persentase susut bobot yang lebih kecil dibandingkan dengan yang lainnya. Bunga bihip pada semua perlakuan terus mengalami peningkatan persentase susut bobot namun peningkatannya tidak sebesar bunga bihip yang diberi perlakuan 1-MCP. Pengaplikasian 1-MCP pada bunga bihip dengan perlakuan yang berbeda dapat menghambat persentase susut bobot bunga karena 1-MCP memblok reseptor etilen sehingga ketersediannya etilen berkurang dan menyebabkan proses respirasi diperlambat. 
J. Hort. Indonesia 5(2):128-136. Agustus 2014.

Tabel 6. Persentase susut bobot bunga potong bihip pada berbagai konsentrasi dan cara aplikasi 1-MCP

\begin{tabular}{|c|c|c|c|c|c|c|c|c|c|c|c|c|}
\hline \multirow{2}{*}{ Perlakuan } & \multicolumn{12}{|c|}{ Umur Bunga (HSP) } \\
\hline & 1 & 2 & 3 & 4 & 5 & 6 & 7 & 8 & 9 & 10 & 11 & 12 \\
\hline \multicolumn{13}{|l|}{ Konsentrasi (A) } \\
\hline $0.0000 \mathrm{ppm}$ & $5.51 \mathrm{a}$ & $11.36 \mathrm{a}$ & $15.43 \mathrm{a}$ & $19.11 \mathrm{a}$ & $22.81 \mathrm{a}$ & $25.06 \mathrm{a}$ & $27.31 \mathrm{a}$ & 29.40 & 31.53 & 33.66 & 34.23 & 36.77 \\
\hline $0.001 \mathrm{ppm}$ & $4.48 b$ & $9.77 b$ & $14.04 \mathrm{~b}$ & $18.12 \mathrm{ab}$ & $21.69 \mathrm{ab}$ & $23.81 \mathrm{ab}$ & $26.03 \mathrm{ab}$ & 29.27 & 31.49 & 34.31 & 37.19 & 39.29 \\
\hline $0.002 \mathrm{ppm}$ & $5.09 \mathrm{ab}$ & $10.73 \mathrm{ab}$ & $14.39 \mathrm{ab}$ & $18.47 \mathrm{a}$ & $22.38 \mathrm{ab}$ & $24.81 \mathrm{a}$ & $27.88 \mathrm{a}$ & 29.92 & 32.73 & 35.58 & 37.87 & 38.42 \\
\hline $0.003 \mathrm{ppm}$ & $2.65 \mathrm{c}$ & $7.67 \mathrm{c}$ & $12.42 \mathrm{c}$ & $16.79 b c$ & $20.88 b c$ & 23.29ab & $26.35 \mathrm{ab}$ & 29.23 & 32.08 & 35.20 & 36.06 & 37.92 \\
\hline $0.004 \mathrm{ppm}$ & $2.85 \mathrm{c}$ & $8.26 \mathrm{c}$ & $12.28 \mathrm{c}$ & $16.39 \mathrm{c}$ & $19.94 \mathrm{c}$ & $22.14 b$ & $24.76 b$ & 27.65 & 30.20 & 32.80 & 33.40 & 35.36 \\
\hline Anova & $* *$ & $* *$ & $* *$ & $* *$ & $* *$ & $*$ & $*$ & tn & tn & tn & tn & tn \\
\hline \multicolumn{13}{|l|}{ Aplikasi (B) } \\
\hline Disemprot & $5.46 \mathrm{a}$ & $10.59 \mathrm{a}$ & $14.54 \mathrm{a}$ & $18.46 \mathrm{a}$ & 21.99 & 24.16 & 26.62 & 29.27 & 31.88 & 34.7 & 36.93 & 38.09 \\
\hline Direndam & $2.76 \mathrm{~b}$ & $8.53 b$ & $12.88 \mathrm{~b}$ & $17.09 \mathrm{~b}$ & 21.09 & 23.48 & 26.31 & 29.01 & 31.44 & 34.27 & 36.09 & 36.07 \\
\hline Anova & $* *$ & $* *$ & $* *$ & $* *$ & tn & tn & tn & tn & tn & tn & tn & tn \\
\hline Interaksi $\mathrm{AxB}$ & tn & tn & tn & tn & tn & tn & $*$ & $* *$ & tn & tn & tn & tn \\
\hline KK & 19.13 & 21.06 & 15.3 & 13.09 & 11.91 & 11.83 & 11.91 & 11.67 & 11.24 & 11.06 & 10.39 & 10.45 \\
\hline
\end{tabular}

Keterangan: *: Berpengaruh nyata pada taraf 5\%; **: Berpengaruh sangat nyata pada taraf $1 \%$; tn: Tidak berpengaruh nyata. Angkaangka yang diikuti huruf yang sama pada kolom yang sama menunjukkan hasil yang tidak berbeda nyata berdasarkan uji DMRT pada taraf $5 \%$.

\section{Uji Hedonik}

Uji hedonik dilakukan dengan cara panelis dimintakan tanggapan pribadinya tentang kesukaan atau ketidaksukaan. Uji hedonik ini dilakukan oleh panelis tidak terlatih selama masa pajang bunga bihip dimana penilaiannya berdasarkan pada penampakan bunga potong bihip secara visual. Skala hedonik pada penelitian ini adalah : $1=$ Tidak suka; 2 = Biasa saja; $3=$ Suka; $4=$ Sangat suka.

Tabel 7. Rekapitulasi analisis ragam pengaruh perlakuan konsentrasi dan cara aplikasi 1-MCP terhadap uji hedonik bunga potong bihip

\begin{tabular}{|c|c|c|c|c|}
\hline Periode & $\mathrm{K}(\mathrm{A})$ & A (B) & $\begin{array}{c}\mathrm{I} \\
\mathrm{AxB}\end{array}$ & $\mathrm{KK}(\%)$ \\
\hline $2 \mathrm{HSP}$ & $* *$ & $*$ & $* *$ & 10.17 \\
\hline $4 \mathrm{HSP}$ & tn & $*$ & tn & 13.79 \\
\hline 6 HSP & tn & $*$ & tn & 27.58 \\
\hline 8 HSP & tn & tn & $* *$ & 20.83 \\
\hline 10 HSP & * & tn & $*$ & $12.81^{\mathrm{Tr}}$ \\
\hline 12 HSP & th & tn & tn & 24.30 \\
\hline
\end{tabular}

Rekapitulasi analisis sidik ragam menunjukkan bahwa adanya interaksi yang nyata antara perlakuan konsentrasi 1-MCP dengan cara aplikasi 1-MCP terhadap uji hedonik bunga potong bihip yaitu hanya pada 2 HSP, 8 HSP, dan 10 HSP. Secara tunggal perlakuan konsentrasi 1-MCP berpengaruh nyata pada 2 HSP dan 10 HSP. Perlakuan cara aplikasi 1-MCP menunjukkan pengaruh nyata pada 2 HSP, 4 HSP, dan 6 HSP (Tabel 7).

Pada tabel 8 menunjukkan bahwa pada 2 HSP para panelis masih menyukai kondisi bunga bihip. Bunga potong bihip masih dalam batas penerimaan yaitu sampai 8 HSP dengan skoring 2, karena saat umur bunga 10 HSP kondisi bunga sudah tidak disukai oleh konsumen. Bunga bihip yang diberi perlakuan 1-MCP dengan konsentrasi $0.004 \mathrm{ppm}$ dan dengan cara aplikasi direndam memiliki nilai yang lebih tinggi dibandingkan dengan perlakuan lainnya. Melalui uji hedonik ini dapat diketahui bahwa umur penerimaan bunga bihip ditentukan oleh keadaan fisik bunga tersebut. Panelis lebih tertarik dengan bunga yang kondisi brakteanya masih sempurna dan masih berwarna kuning atau sedikit bercak coklat dan warna tangkai yang masih hijau. 
Tabel 8. Uji hedonik bunga potong bihip pada berbagai konsentrasi dan cara aplikasi 1-MCP

\begin{tabular}{|c|c|c|c|c|c|c|}
\hline \multirow{2}{*}{ Perlakuan } & \multicolumn{6}{|c|}{ Umur Bunga (HSP) } \\
\hline & 2 & 4 & 6 & 8 & 10 & 12 \\
\hline \multicolumn{7}{|l|}{ Konsentrasi (A) } \\
\hline $0.000 \mathrm{ppm}$ & $3.75 \mathrm{ab}$ & 2.85 & 2.35 & 2 & $1.17 \mathrm{~b}$ & 1 \\
\hline $0.001 \mathrm{ppm}$ & $3.85 \mathrm{a}$ & 2.85 & 2.7 & 2.06 & $1.06 \mathrm{~b}$ & 1 \\
\hline $0.002 \mathrm{ppm}$ & $3.60 \mathrm{~b}$ & 3.00 & 2.9 & 2.3 & $1.44 \mathrm{ab}$ & 1 \\
\hline $0.003 \mathrm{ppm}$ & $3.10 \mathrm{c}$ & 2.80 & 2.6 & 2.25 & $1.31 \mathrm{~b}$ & 1.25 \\
\hline $0.004 \mathrm{ppm}$ & $3.20 \mathrm{c}$ & 2.80 & 2.55 & 2.44 & $1.75 \mathrm{a}$ & 1.67 \\
\hline Anova & $* *$ & tn & tn & tn & $*$ & tn \\
\hline \multicolumn{7}{|l|}{ Aplikasi (B) } \\
\hline Disemprot & $3.50 \mathrm{a}$ & $2.78 b$ & $2.46 \mathrm{~b}$ & 2.16 & 1.26 & 1 \\
\hline Direndam & $3.50 \mathrm{a}$ & $2.94 \mathrm{a}$ & $2.78 \mathrm{a}$ & 2.26 & 1.43 & 1.5 \\
\hline Anova & $*$ & $*$ & $*$ & tn & tn & tn \\
\hline Interaksi $\mathrm{AxB}$ & $* *$ & tn & tn & $* *$ & $*$ & tn \\
\hline KK & 10.17 & 13.79 & 27.58 & 20.83 & 12.81 & 24.3 \\
\hline
\end{tabular}

\section{Vase life}

Vase life bunga potong merupakan lamanya umur relatif bunga potong dalam keadaan tetap segar dan indah setelah dipotong dari tanaman induknya (Wiryanto, 1993). Pengamatan vase life dilakukan mulai dari awal perlakuan hingga $30 \%$ dari keseluruhan braktea berubah warna (Direktorat Budidaya Tanaman pada Hias 2006). Perubahan warna yang terjadi bunga potong bihip ini yaitu warna braktea menjadi berwarna coklat.

Pada tabel 9 menunjukkan bahwa bunga bihip yang tidak diberi perlakuan 1-MCP memiliki vase life yang lebih singkat dibandingkan dengan bunga bihip lainnya yang diberi perlakuan 1-MCP. Bunga bihip yang diberi perlakuan 1-MCP dengan konsentrasi $0.004 \mathrm{ppm}$ memiliki vase life yang lebih lama yaitu 11.30 hari. Sementara itu bunga bihip yang diberi perlakuan 1-MCP dengan cara aplikasi direndam memiliki vase life 11.10 hari. Hal tersebut menunjukkan bahwa perlakuan dengan 1-MCP mempengaruhi vase life bunga bihip. Mekanisme aksi senyawa 1-MCP adalah dengan memblokir reseptor etilen yang ada pada tanaman sehingga etilen tidak dapat menempati reseptor tersebut. 1-MCP menyebabbkan etilen menurunkan laju respirasi yang berpengaruh pada vase life bunga potong, semakin menurunnya laju respirasi maka vase life bunga potong menjadi semakin lama (Setyadjit et al., 2012).
Tabel 9. Vase life bunga potong bihip pada berbagai konsentrasi dan cara aplikasi 1-MCP

\begin{tabular}{|c|c|}
\hline Perlakuan & Vase Life (HSP) \\
\hline \multicolumn{2}{|l|}{ Konsentrasi (A) } \\
\hline $0.000 \mathrm{ppm}$ & $9.55 b$ \\
\hline $0.001 \mathrm{ppm}$ & $10.20 \mathrm{ab}$ \\
\hline $0.002 \mathrm{ppm}$ & $10.75 \mathrm{ab}$ \\
\hline $0.003 \mathrm{ppm}$ & $10.05 b$ \\
\hline $0.004 \mathrm{ppm}$ & $11.30 \mathrm{a}$ \\
\hline Anova & $*$ \\
\hline \multicolumn{2}{|l|}{ Aplikasi (B) } \\
\hline Disemprot & $9.64 \mathrm{~b}$ \\
\hline Direndam & $11.10 \mathrm{a}$ \\
\hline Anova & $* *$ \\
\hline Interaksi AxB & $* *$ \\
\hline KK & 17.31 \\
\hline $\begin{array}{r}\text { Keterangan: *: Berp } \\
\text { Berpeng } \\
\text { Tidak b } \\
\text { dikuti h } \\
\text { menunju } \\
\text { berdasar }\end{array}$ & $\begin{array}{l}\text { yata pada taraf } 5 \% ; * * \text {; } \\
\text { t nyata pada taraf } 1 \% \% \text {; tn: } \\
\text { nyata. Angka-angka yang } \\
\text { ama pada kolom yang sama } \\
\text { yang tidak berbeda nyata } \\
\text { RT pada taraf } 5 \% \text {. }\end{array}$ \\
\hline
\end{tabular}

Menurut Balai Penelitian Tanaman Hias (2011), lama kesegaran bunga potong bihip tanpa pemberian bahan pengawet dapat mencapai 7 hari dan bunga ini responsif terhadap bahan pengawet. Perlakuan pasca panen yang dilakukam pada bunga potong 
bihip ini antara lain disimpan pada suhu rendah dengan kelembaban yang tinggi dan dilakukan dengan merendam tangkai bunga dalam air serta menghindari penyimpanan dalam kondisi kering.

Berdasarkan uji hedonik bunga bihip batas penerimaan bunga bihip hanya sampai 8 HSP, namun pada pengujian vase life bunga bihip dapat mencapai 11 HSP. Perbedaan kedua hal tersebut dikarenakan uji hedonik dilakukan secara objektif oleh para panelis yang tidak terlatih dan sebagian besar panelis menyukai bunga yang masih berwarna kuning atau dengan sedikit warna kecoklatan. Sementara itu pengukuran vase life bunga potong bihip tersebut berdasarkan parameter $30 \%$ keseluruhan braktea berubah warna menjadi coklat.

\section{KESIMPULAN}

Perlakuan 1-MCP secara nyata dapat memperpanjang vase life bunga potong bihip (Zingiber spectabile Griff. Silvana) hingga mencapai 11.30 hari dibandingkan dengan tanpa perlakuan 1-MCP yaitu hanya 9.55 hari. Konsentrasi 1-MCP yang optimum untuk memperpanjang vase life bunga potong bihip hingga 11.30 hari yaitu dengan konsentrasi 0.004 ppm. Cara aplikasi 1-MCP yang efisien untuk memperpanjang bunga bihip hingga 11.10 hari yaitu dengan cara merendam bunga dalam larutan 1-MCP. Kombinasi perlakuan 1-MCP yang dapat memperpanjang vase life bunga bihip yaitu perlakuan 1-MCP konsentrasi 0.004 ppm dengan cara aplikasi direndam.

\section{SARAN}

Perlunya penelitian lebih lanjut dengan aplikasi 1-MCP pada bunga bihip dengan selang waktu dari panen hingga pengaplikasian yang lebih singkat dari penelitian ini. Perlunya penelitian lebih lanjut tentang aplikasi 1-MCP dengan taraf konsentrasi yang lebih tinggi dari penelitian ini.

\section{DAFTAR PUSTAKA}

Balai Tanaman Hias. 2011. Masa kesegaran bunga potong Zingiber. http://balithi.litbang. deptan.go.id. [23 September 2013].

Bhattacharjee, S.K., L.C. De. 2005. Post-harvest Technology of Flowers and Ornamental Plants. Jaipur. Pointer Publisher.

Blakenship, S.M., J.M. Dole. 2003. 1-Methyl cyclopropene: a review. Postharvest Biol. Technol. 28: 1-25.

[Ditflorikultura] Direktorat Budidaya Tanaman Hias. 2006. Standar Prosedur Operasional Zingiberaceae [Internet]. [diunduh 2013 September 24]. Tersedia pada florikultura .org/pedum/SOP_Zingiberaceae.pdf.

Direktorat Jenderal Hortikultura. 2014. Florikultura Tahun 2011-2013. hortikultura. pertanian.go.id [24 April 2014].

Larsen, K., H. Ibrahim, S. H. Khaw, L. G. Saw. 1999. Gingers of Peninsular Malaysia and Singapore. Natural History Pub. (Borneo). $135 \mathrm{p}$.

Salsabila, Ilsa. 2013. Aplikasi 1-Methyl cyclopropene untuk meningkatkan vase life bunga potong Tapeinochilos anannaceae K. Schum. Skripsi. Institut Pertanian Bogor. Bogor.

Santoso, B.B. 2012. Penyimpanan komoditi hortikultura. 121-122. http://fp.unram.ac. id. [23 September 2013].

Setyadjit, E. Sukasih, A.W. Permana. 2012. Aplikasi 1-MCP dapat memperpanjang umur segar komoditas hortikultura. Bul. Teknologi Pascapanen Pertanian. Vol. 8(1): 28-29.

Sisler, E.C., M. Serek. 1997. Inhibitors of ethylene responses in planta at the receptor level: recent developments. Physiol Plant. 100:577-582.

Wiryanto, K. 1993. Penanganan pasca panen bunga anggrek. Buletin Anggrek. 06:20. 